Fisher, T., Fisher, E. \& Appleman, M. D. (1956). J. gen. Microbiol. 14, 238-247

\title{
Nitrite Production by Heterotrophic Bacteria
}

\author{
By THELMA FISHER*, E. FISHER $\uparrow$ AND M. D. APPLEMAN \\ Department of Bacteriology, University of Southern California, Los Angeles, \\ California, U.S.A.
}

SUMMARY: Heterotrophic bacteria were studied which produced nitrite in the presence of ammonia and in the absence of nitrate. A soil extract medium was prepared which allowed good growth as well as nitrite production in the absence of nitrate. Quantitative data are recorded showing that ammonia decreases as nitrite accumulates when four different cultures are grown in the soil medium. Resting cell studies add further evidence that some heterotrophic bacteria can convert ammonia to nitrite.

A defined medium was prepared containing glucose or sodium acetate as the carbon source and $\mathrm{NH}_{4} \mathrm{Cl}$ as the nitrogen source. This medium supported growth and nitrite production; however, optimum conditions for growth were not established. Neither growth nor nitrite accumulation was as great in defined media as in soil-extract media. Results from defined media and from resting-cell studies rule out the possibility of any nitrate contamination.

Early in the literature reports were published by Fremlin (1903, 1914, 1929), Makrinoff (1909), Cutler (1930), Cutler \& Mukerji (1931), Cutler \& Crump (1933), Crump (1935), Nechaeva (1947) and others suggesting the possibility of nitrification by heterotrophic bacteria. Recently Fisher, Fisher \& Appleman (1952) and Hutton \& ZoBell (1953) have added more data supporting these early observations. Isenberg et al. (1954) described a streptomycete which produces nitrite from urethane.

This paper presents evidence that certain Gram-negative bacteria isolated from soil form nitrite in the presence of ammonia in defined and undefined media. Ammonia disappears as nitrite is produced. Special precautions have been taken to exclude nitrate from the media.

\section{METHODS}

Bacteria. Sixteen nitrite-producing cultures were obtained from soil by enrichment techniques. These were shown to be pure. The organisms were found to be Gram-negative short rods probably belonging to group 2 or 3 of Taylor \& Lochhead's (1938) classification of soil bacteria. This classification, based on morphology and Gram-staining reactions of cultures grown on soil extract semi-solid agar, has eight large subdivisions, group 2 consisting of short Gram-negative rods and group 3 composed of short Gram-variable rods.

\footnotetext{
* Present address: Department of Preventive Medicine, Western Reserve University, Cleveland, Ohio, U.S.A.

$\dagger$ Present address: Department of Microbiology, Western Reserve University, Cleveland, Ohio, U.S.A.
} 
Organisms in group 2 were least active physiologically and were thought to comprise much of the indigenous soil flora. Organisms selected for this particular study produced nitrite in the presence of ammonia and in the absence of nitrate. Cultures designated $8_{5}, 14_{9}$ and 54 did not produce acid when grown in the presence of glucose, mannitol, lactose, sucrose or maltose. They were $\mathrm{H}_{2} \mathrm{~S}$ - and indole-negative, non-motile, produced an alkaline reaction or reduction and peptonization in litmus milk, and they were able to reduce nitrate. Cultures 19, 20, 31, 33, 40, 43 and 45 did not produce acid in the presence of the sugars mentioned. They were $\mathrm{H}_{2} \mathrm{~S}$ - and indole-negative and did not reduce nitrate. They produced an alkaline reaction in litmus milk, and were motile. Culture 13 was even less active physiologically in that acid was not produced in the sugar broths; there was no growth in $\mathrm{H}_{2} \mathrm{~S}$, indole, litmus milk or gelatin media and it was found to be non-motile. Cultures 10, 15 and 17 produced acid and gas in media containing the five sugars; $\mathrm{H}_{2} \mathrm{~S}$ and indole were not produced; they could reduce nitrate, formed acid and coagulated litmus milk, liquefied gelatin, and were motile. Cultures 30 and $\mathbf{3 4}$ produced acid in glucose but not in other sugars. Tests were negative for $\mathrm{H}_{2} \mathrm{~S}$ and indole production, for gelatin liquefaction, and for motility. They could reduce nitrate but showed no change in milk. Further attempts to classify these organisms, including a key for the separation of isolates, were presented by Fisher (1953). All cultures grew on nutrient agar but would not grow on Winogradsky's autotrophic media for nitrifiers. Cultures $\mathbf{8}_{5}, 10,14_{9}$ and 54 were selected for intensive study since these organisms showed consistently heavier cell growth in most of the culture preparations.

Media. The undefined medium generally employed contained $50 \%(\mathrm{v} / \mathrm{v})$ soil

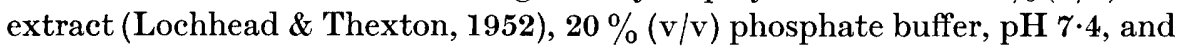
$0.01 \%(\mathrm{w} / \mathrm{v})\left(\mathrm{NH}_{4}\right)_{2} \mathrm{CO}_{3}$. The components and preparation of this medium will be described. Soil extract: $1 \mathrm{~kg}$. of soil from the Los Angeles area (very low or negative for nitrite and nitrate) was added to 11 . distilled water and the mixture autoclaved at $15 \mathrm{lb}$./sq.in. for $30 \mathrm{~min}$. A small amount of $\mathrm{CaCO}_{3}$ was introduced into the suspension after autoclaving while the material was still hot. The preparation was filtered. This was considered $100 \%$ soil extract. Buffer: best results were obtained when phosphate buffer, $\mathrm{pH} \mathbf{7 \cdot 4}$, was prepared as follows: $\mathrm{Na}_{2} \mathrm{HPO}_{4} \cdot 7 \mathrm{H}_{2} \mathrm{O} 2 \cdot 745 \mathrm{~g}$. dissolved in $200 \mathrm{ml} . \mathrm{H}_{2} \mathrm{O} ; \mathrm{KH}_{2} \mathrm{PO}_{4}$ $0.4213 \mathrm{~g}$. dissolved in $200 \mathrm{ml} . \mathrm{H}_{2} \mathrm{O}$. The two solutions were mixed in equal volumes. The $50 \%$ soil extract medium was assembled in the following proportions :

$\begin{array}{ll}\text { Soil extract } & 50 \mathrm{ml} . \\ \text { Mixed phosphate buffer } & 20 \mathrm{ml} . \\ \text { Distilled water } & 30 \mathrm{ml} . \\ \left(\mathrm{NH}_{4}\right)_{2} \mathrm{CO}_{3} & 0.01 \mathrm{~g} .\end{array}$

The medium was autoclaved at $15 \mathrm{lb}$./sq.in. for $20 \mathrm{~min}$. which allowed the $\mathrm{pH}$ value to hold between $7 \cdot 2$ and $7 \cdot 5$ under the above conditions. A $10 \%$ soil extract medium had the same constituents as the $50 \%$ medium except that $10 \mathrm{ml}$. of the concentrated soil extract was used instead of $50 \mathrm{ml}$., maintaining 
the total volume at $100 \mathrm{ml}$. When a solid medium was required, $1.25 \%$ washed agar was added to the above medium. Stock cultures were stored in $\mathbf{0 . 3} \%$ semisolid soil extract agar. Soil extract media were placed in $6 \mathrm{oz}$. bottles so that the bottles were approximately half full or in screw cap test-tubes $(16 \times 120 \mathrm{~mm}$.) and half-filled before autoclaving. After inoculation, tube or bottle tops were generally screwed on lightly so that anaerobiosis was not obtained.

All glassware used was acid cleaned to eliminate traces of nitrate. Care was taken to maintain nitrate-free water and reagents. Media controls were run with each experiment to be sure the media did not pick up any nitrogenous oxides from the air which might give positive nitrite tests.

The defined medium contained $0.5 \%$ glucose or $0.5 \%$ sodium acetate as the carbon source. Ammonium chloride was used in concentrations of 0.01 or $0.03 \%$. The other constituents consisted of $0.61 \%$ Tris (hydroxymethyl) aminomethane buffer adjusted to $\mathrm{pH} 7 \cdot 4$ with $\mathrm{HCl}, 0.01 \% \mathrm{NaHCO}_{3}, 0.06 \%$ $\mathrm{MgSO}_{4}$, a trace of $\mathrm{CaCl}_{2}$ and phosphates. The medium was autoclaved at $15 \mathrm{lb}$./ sq.in. for $20 \mathrm{~min}$.

Analytical procedures. A modified Griess-Illosva method (Griess, 1858; Illosva, 1889) was used for nitrite determinations. Reagents were prepared according to the procedure in Methods of Analysis of the Association of Official Agricultural Chemists (1935). By this method $25 \mathrm{ml}$. of the diluted sample were tested. Two drops of concentrated $\mathrm{HCl}$ were added to the sample, followed by $1 \mathrm{ml}$. of sulphanilic acid solution and the contents mixed. $1 \mathrm{ml}$. of $\alpha$-naphthylamine hydrochloride reagent was then introduced, the tube contents were mixed thoroughly and readings were taken in $30 \mathrm{~min}$. Duplicate portions of each of several dilutions were tested as described. A standard curve was prepared, but each time determinations were run several dilutions of the standard samples were tested to be sure the curve was still accurate. Transmission readings were made in the Klett-Summerson colorimeter (540 filter) or the Beckman DU spectrophotometer ( $525 \mathrm{~m} \mu$. wavelength). Wallace \& Neave (1927) reported that the colorimetric nitrite test used was sensitive to 1 part of nitrite in 100 million of solution.

A modification of Bray's method (1945) to determine nitrate was used. This follows the same procedure as the nitrite test except that an acid suspension of powdered zinc was added to a mixture of the reagents and these in turn were introduced into the sample to be tested. A red colour developed just as in the nitrite test so that the same standard curve was used for both determinations. Known quantities of nitrate were also tested in duplicate as controls, each time to insure the sensitivity of the method and reliability of reagents. This method for nitrate was found to be as sensitive as the nitrite test.

Qualitative tests for nitrite and nitrate were measured using the reagents described for quantitative testing, except that values obtained were designated 1, 2, 3 and 4 plus depending on relative colour intensities upon gross examination.

Ammonia was determined by the colorimetric nesslerization method as listed in Wilson \& Knight (1949). A distillation method was used to obtain 
samples for colorimetric analysis. An ammonia-free water blank was boiled $10 \mathrm{~min}$. to remove any ammonia from the apparatus. A $15 \mathrm{ml}$. sample of culture medium centrifuged free from organisms was placed in the ammonia-free flask containing $10 \mathrm{ml}$. distilled water. $10 \mathrm{ml}$. of concentrated $\mathrm{NaOH}$ was added to the closed system and by heating gently for $10 \mathrm{~min}$. ammonia was driven over through a water-cooled condenser to a flask containing a weak solution of $\mathrm{HCl}$. The total volume of distillate collected was recorded since portions of this distillate were used to determine the amount of ammonia/ml. in the original sample. Two to three samples of the same culture medium were distilled over as described in the method above. Triplicate samples of each distillate were tested colorimetrically. The values obtained corresponded very closely.

To test qualitatively for the presence of ammonia, Nessler's reagent was added to a sample solution and the development of a dark yellow colour was considered a 4 plus positive test. Gradations less than this in colour intensity were designated 3,2 and 1 plus positive.

\section{RESULTS}

Optimum conditions for growth and nitrite production. A $10 \%$ soil extract medium had been used to isolate the cultures studied. Since this medium was found to be minimal for growth a $\mathbf{5 0} \%$ soil extract medium was prepared and adjusted to various $\mathrm{pH}$ values with $\mathrm{HCl}$ or $\mathrm{NaOH}$ before autoclaving. The medium was positive for ammonia and negative for nitrite and nitrate as determined by procedures described in the methods section. The $\mathrm{pH}$ value of the medium was adjusted to the values: $6 \cdot 8,7 \cdot 0,7 \cdot 2,7 \cdot 4,7 \cdot 6,7 \cdot 8,8 \cdot 0$ and $8 \cdot 4$. Of the four cultures tested in these media $\left(8_{5}, 10,14_{9}\right.$ and 54$)$ growth of all cultures occurred from $\mathrm{pH} 6 \cdot 8$ to $8 \cdot 0$. Growth was best at $\mathrm{pH} 7 \cdot 4$ and good at $\mathrm{pH} 7 \cdot 2$. Nitrite production was good at $\mathrm{pH} \mathbf{7 \cdot 4}$ and $\mathbf{7 \cdot 2}$.

It was shown that nitrite production increased with an increase in organism numbers. Observations indicated that maximum growth in $50 \%$ soil extract media was obtained in about 2 days while nitrite formation continued to increase until a peak was reached in approximately 4 days when the cultures were incubated at $30^{\circ}$. The fact that nitrite production increases with an increase in number of organisms and continues to increase for a short time after maximum growth is attained, suggests that nitrite accumulation is due to the biological agent.

\section{Nitrite accumulation and ammonia disappearance in soil extract medium}

The four cultures were grown in $50 \%$ soil extract medium at $30^{\circ}$ in $6 \mathrm{oz}$. screw-cap bottles half-filled with medium. The cultures were incubated for 22 days. The medium, centrifuged free of cells, was then tested for nitrite, nitrate and ammonia by the quantitative methods described. The uninoculated control media contained only trace amounts or no nitrite or nitrate so that these results are recorded as 'less than' a certain value. Nitrite and nitrate 
ions have never been found to be present in the soil extract media used in more than trace amounts.

Values for ammonia nitrite and nitrate, as well as the possible percentage conversion of ammonia nitrogen to nitrite nitrogen, are recorded in Table 1. These data show that ammonia disappears as nitrite accumulates when cultures $8_{5}, 10,14_{9}$ and 54 grow in soil extract medium. Eighty-seven $\%$ of the ammonia lost was recovered as nitrite in culture 54. This was the highest value obtained. Sixty-three $\%$ of the ammonia lost was recovered as nitrite in culture $14_{9}$. This was the lowest recovery value observed. These data show that nitrite accumulated as ammonia simultaneously disappeared in the absence of nitrate, suggesting a conversion of ammonia to nitrite.

When preparations of $100 \%$ soil extract were tested by micro-Kjeldahl determinations, a different value of total nitrogen was obtained for different soil samples tested. This was expected, due to the many variables in soil as well as due to evaporation and concentration which occurs during the autoclaving process. A defined medium for nitrification studies was considered necessary to eliminate such variables and rule out any suspicion of conversion of nitrate to nitrite. This is considered later.

Increase in nitrite production with an increase in ammonia concentration. In order to show that nitrite accumulation increases with increased amounts of ammonia, $50 \%$ soil extract buffered at $\mathrm{pH} 7 \cdot 4$ with Tris was used as one medium, while other portions were fortified with 0.01 or $0.03 \% \mathrm{NH}_{4} \mathrm{Cl}$. Cultures were incubated 10 days at $30^{\circ}$, centrifuged free of cells and tested for nitrite and nitrate. These findings are recorded in Table 2 . Nitrite production was greatly increased when $0.01 \% \mathrm{NH}_{4} \mathrm{Cl}$ was included in the medium. When the $\mathrm{NH}_{4} \mathrm{Cl}$ concentration was increased above the $0.01 \%$ level no rise in the nitrite concentration was obtained. The optimum concentration for nitrite production by these cells in these media seemed to be at or near the $0.01 \%$ $\mathrm{NH}_{4} \mathrm{Cl}$ concentration when $\mathbf{5 0} \%$ soil extract is present. Soil extract alone gave a 4 plus positive qualitative Nessler's test for ammonia, but this concentration apparently is not high enough to support optimum heterotrophic nitrite production. Tests for nitrate were negative on all solutions used.

Growth and nitrite production in defined media. Organisms designated $8_{5}$ and $14_{9}$ were inoculated into the two defined media, one containing sodium acetate as the carbon source and the other containing glucose. Nitrite production under these conditions is reported in Table 3. In both cases the growth obtained in defined media was somewhat less than maximum compared to that observed when these bacteria were grown in soil extract media.

When defined media were used for growth and nitrite formation, nitrite increased as the cultures were incubated for 7 days. After 7 days of growth, nitrite values reached a peak, remained stationary for several days then dropped slowly. Values reported for nitrite production by heterotrophic bacteria in defined media are lower than those in soil extract media. However, since the sensitivity of the nitrite and nitrate methods permit the measurement of values much lower than those obtained and since the media are defined and all possibility of nitrate inclusion or contamination is eliminated, 


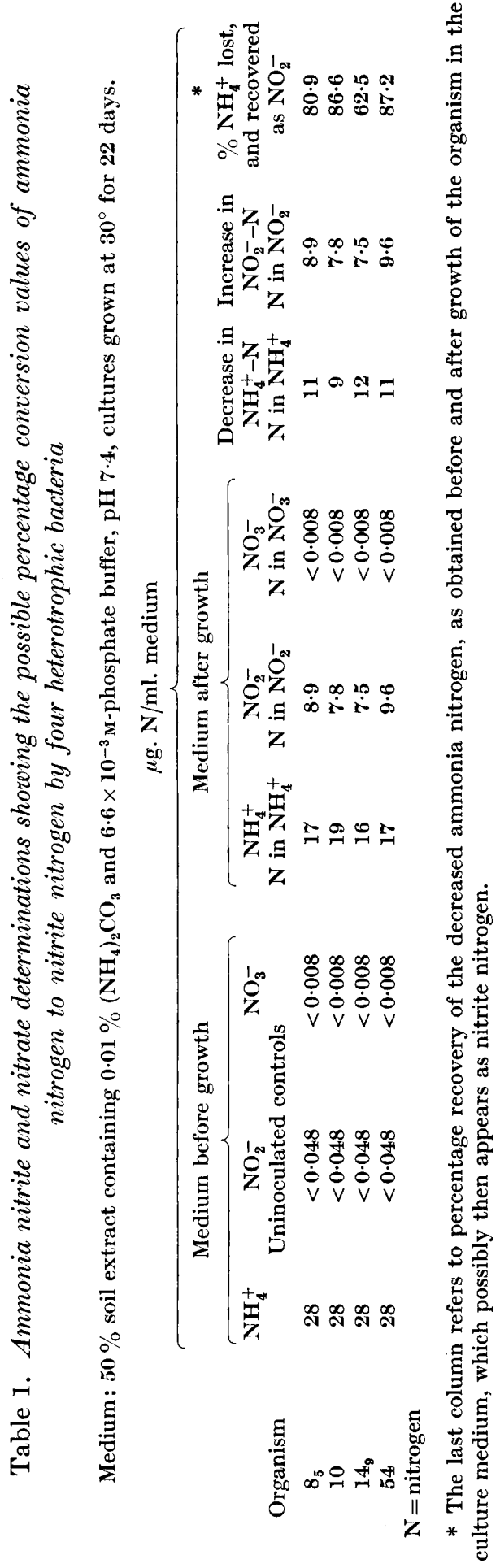


it is evident that these bacteria do produce nitrite in the presence of ammonia and in the absence of nitrate. Optimum conditions for growth and nitrite production in synthetic media have not been established.

Table 2. Nitrite produced by two bacterial cultures, $\mathbf{8}_{5}$ and $\mathbf{1 4}_{9}$, grown in soil extract medium

Medium : $50 \%$ soil extract containing $0,0.01$ or $0.03 \% \mathrm{NH}_{4} \mathrm{Cl}$ and $6.6 \times 10^{-3} \mathrm{M}$-phosphate buffer, $\mathrm{pH} 7 \cdot 4$, cultures grown at $30^{\circ}$ for 10 days.

\begin{tabular}{|c|c|c|c|}
\hline \multirow{3}{*}{ Organism } & \multicolumn{3}{|c|}{ Concentration of $\mathrm{NH}_{4} \mathrm{Cl}(\%)$} \\
\hline & 0 & 0.01 & 0.03 \\
\hline & \multicolumn{3}{|c|}{$\mu \mathrm{g} . \mathrm{NO}_{\mathbf{2}}^{-}-\mathrm{N} / \mathrm{ml}$} \\
\hline $8_{5}$ & $5 \cdot 8$ & 11 & 10 \\
\hline $14_{9}$ & 3 & 16 & 16 \\
\hline $\begin{array}{l}\text { Medium } \\
\text { control }\end{array}$ & 0 & $\mathbf{0}$ & 0 \\
\hline
\end{tabular}

Tests for nitrate were negative on all samples.

Table 3. Nitrite production by cultures $8_{5}$ and $14_{9}$ when grown in a defined medium

Defined medium: $0.5 \%$ sodium acetate or $0.5 \%$ glucose, $0.01 \% \mathrm{NH}_{4} \mathrm{Cl}, 0.61 \%$ Tris (hydroxymethyl) aminomethane buffer, pH 7.4, $0.01 \% \mathrm{NaHCO}_{3}, 0.06 \% \mathrm{MgSO}_{4}$, a trace of $\mathrm{CaCl}_{2}$ and phosphates. Cultures grown at $30^{\circ}$ for 7 days.

\begin{tabular}{|c|c|c|c|c|}
\hline \multirow[b]{2}{*}{ Experiment } & \multirow[b]{2}{*}{ Organism } & & \multirow{2}{*}{$\begin{array}{r}\mu \mathrm{g} . \mathrm{NO}_{3}^{-}-\mathrm{N} / \mathrm{ml} . \\
3 \text { and } 7 \text { days }\end{array}$} \\
\hline & & 3 days & 7 days & \\
\hline $\begin{array}{l}\text { 1. Sodium acetate the } \\
\text { carbon source }\end{array}$ & $\begin{array}{l}8_{5} \\
14_{9} \\
\text { Medium control } \\
\text { no growth }\end{array}$ & $\begin{array}{l}0 \cdot 14 \\
0 \cdot 10 \\
0\end{array}$ & $\begin{array}{l}0 \cdot 19 \\
0 \cdot 19 \\
0\end{array}$ & $\begin{array}{l}\mathbf{0} \\
\mathbf{0} \\
\mathbf{0}\end{array}$ \\
\hline $\begin{array}{l}\text { 2. Glucose the carbon } \\
\text { source }\end{array}$ & $\begin{array}{l}8_{5} \\
14_{9} \\
\text { Medium control } \\
\text { no growth }\end{array}$ & $\begin{array}{l}0 \cdot 12 \\
0 \cdot 10 \\
0\end{array}$ & $\begin{array}{l}0 \cdot 19 \\
0 \cdot 18 \\
0\end{array}$ & $\begin{array}{l}\mathbf{0} \\
\mathbf{0} \\
0\end{array}$ \\
\hline
\end{tabular}

Resting-cell studies and nitrite production. Culture $14_{9}$ was grown on nutrient agar slopes for $20 \mathrm{hr}$. at $30^{\circ}$ and washed three times in sterile distilled water. Organisms and supernatant were negative for nitrite and nitrate by the methods previously described. A solution composed of $0.08 \mathrm{M}$-phosphate buffer and $0.01 \%\left(\mathrm{NH}_{4}\right)_{2} \mathrm{CO}_{3}$ was used. To a portion of the latter, $2 \mathrm{ml}$. of washed organisms $\left(7 \times 10^{8} / \mathrm{ml}\right.$.) were introduced. These were maintained in screwcap test-tubes measuring $20 \times 120 \mathrm{~mm}$. and filled over three-quarters full with solution. Tubes were tightly sealed and samples placed in the $37^{\circ}$ incubator. Small portions of the suspension and the control were removed at the same time interval to test for nitrite production. The control remained negative for nitrite and nitrate throughout the experiment. A positive nitrite test was obtained after $54 \mathrm{hr}$. of incubation of the resting-cell mixture. This was con- 
sidered a 1 plus positive test as described in the methods section. By $194 \mathrm{hr}$. the qualitative test for nitrite was 2 plus positive. The test for nitrate was negative at both time intervals.

Other cultures known to produce nitrite in soil extract media were also tested. After washing, however, the organisms were suspended in $\left(\mathrm{NH}_{4}\right)_{2} \mathbf{H P O}_{4}$ instead of the $\left(\mathrm{NH}_{4}\right)_{2} \mathrm{CO}_{3}$ substrate. These suspensions were incubated as before. Tests for nitrite and nitrate were negative at all times on the control substrate. A positive reaction for nitrate was never obtained on the test samples. By the end of $71 \mathrm{hr}$. incubation suspensions from nine different bacterial preparations gave positive tests for nitrite ranging from slight to 2 plus reactions. Most of the positive nitrite tests were obtained after $39 \mathrm{hr}$. incubation but some of the reactions were only slight at that time. The amount of nitrite produced by resting organisms was never as great as the amount produced when the organisms grew in soil extract medium. Nitrite production seems to be greatly increased by growth of the bacterial agent, however restingcell observations further the idea of nitrite production by heterotrophs since the possibility of contamination in the system with traces of nitrite or nitrate is reduced.

\section{DISCUSSION}

The data reported in Table 1 strongly suggest the conversion of ammonia to nitrite, since ammonia disappeared as nitrite was formed in the absence of nitrate. In one instance as much as $87 \%$ of the removed ammonia nitrogen could be accounted for as nitrite nitrogen. These findings do not necessarily imply that the mechanism for conversion of ammonia to nitrite by heterotrophic bacteria is the same as that employed by autotrophic bacteria. We know that smaller amounts of nitrite are produced by heterotrophs than by autotrophs. A comparative investigation of the mechanisms of conversion of ammonia to nitrite by heterotrophic and autotrophic bacteria using labelled nitrogen techniques might be rewarding.

Micro-Kjeldahl analysis of soil extract indicates that ammonia is not the only nitrogenous constituent in soil extract. Unknown nitrogenous components as well as ammonia may play roles in nitrite formation. It is conceivable that ammonia could be incorporated into cell protein while another nitrogenous component, other than nitrate, might be converted to nitrite. At any rate, ammonia disappears as nitrite appears and nitrate is not present in the system either before or after conversion under the conditions studied.

Resting-cell observations, as well as growth studies in defined media, point towards the conversion of ammonia to nitrite. Under these conditions any possibility of nitrate contamination is eliminated.

It has not been shown that all the nitrite produced comes from ammonia in the soil extract medium. It may be that nitrite production by heterotrophic bacteria is a more inclusive process than that conducted by autotrophic bacteria. The fact that heterotrophic bacteria participate in nitrite formation in the absence of nitrate suggests that the process is more universal than was formerly suspected. 
No mention has been made concerning the importance of this reaction as an energy source. The amount of nitrite produced by heterotrophic bacteria compared to that produced by autotrophic organisms would suggest that heterotrophic nitrification is not an important energy-yielding mechanism for these bacteria. However, since small Gram-negative rods of groups $\mathbf{2}$ and $\mathbf{3}$ are considered the most prevalent morphological types in soil (Taylor \& Lochhead, 1938; Conn, 1917 $a, b, 1948)$ it may be that these heterotrophic bacteria contribute substantially to the nitrogen cycle in soil.

\section{REFERENCES}

Bray, R. H. (1945). Nitrate tests for soils and plant tissues. Soil Sci. 60, 219.

ConN, H. J. (1917 a). Soil flora studies. I. The general characteristics of the microscopic flora of soil. II. Methods best adapted to the study of the soil flora. Tech. Bull. N.Y. St. agric. Exp. Sta., no. 58.

Cons, H. J. $(1917 b)$. Soil flora studies. IV. Non-spore-forming bacteria in soil. Tech. Bull. N.Y. St. agric. Exp. Sta., no. 59.

Cons, H. J. (1948). The most abundant groups of bacteria in soil. Bact. Rev. 12, 257.

Crump, L. M. (1935). The formation of nitrite by heterotrophic bacteria from soil. Trans. 3rd Int. Congr. Soil Sci. 3, 103.

Cutler, D. W. (1930). Nitrifying bacteria. Nature, Lond., 125, 168.

Cutler, D. W. \& Crump, L. M. (1933). Some aspects of the physiology of certain nitrite-forming bacteria. Ann. appl. Biol. 20, 291.

Cutler, D. W. \& MukerJI, B. K. (1931). Nitrite formation by soil bacteria other than Nitrosomonas. Proc. roy. Soc. B, 108, 384.

Frsher, T. (1953). Studies on nitrification by heterotrophic bacteria. Ph.D. thesis. University of Southern California.

Fisher, T., Fisher, E. \& Appleman, M. D. (1952). Nitrification by certain heterotrophic bacteria present in soil. J. Bact. 64, 596.

Fremin, H. L. (1903). On the culture of the nitrosobacterium. Proc. roy. Soc. 71, 356.

Fremlin, H. L. (1914). Further observations on nitroso-bacteria. J.Hyg., Camb., 14, 149.

Fremlin, H. L. (1929). Further notes on the culture of the nitroso-bacterium. J. Hyg., Camb. 29, 236.

Griess, P. (1858). Vorläufige Notiz über die Einwirkung von salpetriger Säure auf amidinitro- und aminitrophenyl-säure. Liebigs Ann. 106, 123.

Hutton, W. E. \& ZoBell, C. E. (1953). Production of nitrite from ammonia by methane oxidizing bacteria. J. Bact. 65, 216.

Illosva, L. I. de N. (1889). L'acide azoteux dans la salive et dans l'air exhalé (IV); Bull. Soc. chim., Paris (3) 2, 388.

Isenberg, H. D., Schatz, A., Angrist, A. A., Schatz, V. \& Trelawny, G. S. (1954). Microbial metabolism of carbamates. II. Nitrification of urethan by Streptomyces nitrificans. J. Bact. 68, 5.

Lochhead, A. G. \& Thexton, R. H. (1952). Qualitative studies of soil microorganisms. X. Bacteria requiring vitamin $\mathrm{B} 12$ as growth factor. J. Bact. 63, 219.

Makrinoff, J. (1909). Magnesia-Gipsplatten und Magnesia-Platten mit organischer Substanz als sehr geeignetes festes Substrat für die Kultur der Nitrifikationsorganismen. Zbl. Bakt. 24, 415. (cited by Cutler, D. W. \& Mukerji, B. K. (1931).

Methods of Analysis of the Association of Official Agricultural Chemists. (1935). Association of Official Agricultural Chemists at Washington, D.C., 37, 506. 
Nechaeva, N. B. (1947). Mycobacteria which oxidize ammonia to nitrites. Mikrobiologiya, 16, 418.

TAYlOR, C. B. \& LochHeAd, A. G. (1938). Qualitative studies of soil micro-organisms. II. A survey of the bacterial flora of soils differing in fertility. Canad. J. Res. C, $16,162$.

Wallace, G. I. \& Neave, S. L. (1927). The nitrite test as applied to bacterial cultures. J. Bact. 14, 377.

Wilson, P. W. \& Knight, S. G. (1949). Experiments in Bacterial Physiology. Minneapolis, Minnesota, U.S.A.: Burgess Publishing Co.

(Received 5 May 1955) 